\title{
Joanna Michalczyk
}

Uniwersytet Ekonomiczny we Wrocławiu

e-mail: joanna.michalczyk@ue.wroc.pl

\section{ZRÓWNOWAŻONE ŁAŃCUCHY DOSTAW ŻYWNOŚCI. WYBRANE INICJATYWY \\ SUSTAINABLE FOOD SUPPLY CHAINS. SELECTED INITIATIVES}

DOI: $10.15611 /$ pn.2018.523.19

JEL Classification: Q01, Q18

Streszczenie: Celem opracowania jest przedstawienie istoty idei zrównoważonego rozwoju oraz jej zastosowania w łańcuchach dostaw żywności - będących przedmiotem zainteresowania polityki wielu państw, zwłaszcza Unii Europejskiej. W związku z tym w artykule została zaprezentowana istota i ewolucja łańcuchów dostaw żywności ze wskazaniem potrzeby wdrażania w ich funkcjonowaniu zasad zrównoważonego rozwoju. Przedstawiono cele zrównoważonych łańcuchów dostaw żywności oraz wybrane inicjatywy i działania wspomagające ich tworzenie oraz funkcjonowanie. Wskazano ponadto przykłady praktyk stosowanych przez przedsiębiorstwa na poszczególnych etapach łańcucha żywnościowego w kierunku zapewnienia zrównoważonego rozwoju oraz korzyści z tym związane. Wykazano, że zrównoważony rozwój staje się jednym z ważniejszych obszarów funkcjonowania łańcuchów dostaw żywności. W opracowaniu posłużono się metodą opisową i analizą literatury.

Słowa kluczowe: zrównoważony rozwój, łańcuchy dostaw, łańcuchy żywnościowe.

Summary: The aim of the study is to present the essence of the idea of sustainable development and its application in food supply chains which are of interest of the policy of many countries, especially European Union member states. Therefore, the article presents the essence and evolution of food supply chains with an indication of the need to implement the principles of sustainable development in their functioning. The goals of sustainable food supply chains as well as selected initiatives and activities supporting their creation and functioning are presented. Moreover, the examples of practices used by enterprises at particular stages of the food chain, directed to ensuring sustainable development, and the related benefits are also indicated. It has been proved that sustainable development is becoming one of the most important areas of the functioning of food supply chains. The study uses the descriptive method and the analysis of literature.

Keywords: sustainable development, supply chains, food chains. 


\section{Wstęp}

W dobie nasilających się zjawisk globalizacji i regionalizacji oraz niebywałego postępu cywilizacyjnego, obok wielu korzyści z nimi związanych, pojawiło się wiele wyzwań i zagrożeń dla dzisiejszych i przyszłych pokoleń. Powstające propozycje sposobów stawienia im czoła są czasochłonne, kosztochłonne i konfliktogenne ze względu na różnice interesów zaangażowanych stron oraz na występowanie wysoce złożonych problemów dotykających jednocześnie wielu obszarów. W efekcie wiele krajów skupiło się na wypracowaniu interdyscyplinarnego podejścia do rozwiązywania problemów współczesnej gospodarki światowej. Opiera się ono na zastosowaniu koncepcji zrównoważonego rozwoju niemal w każdym obszarze funkcjonowania człowieka - począwszy od rolnictwa i przemysłu wydobywczego, a skończywszy na dziedzinach powstałych stosunkowo niedawno, opartych na zaawansowanych technologiach. Wspomniana idea pozwala zapewnić w miarę możliwości stabilny, równomierny i nieprzerwany rozwój ludzkości z jednoczesnym zachowaniem sprawiedliwości międzypokoleniowej, nakładającej na obecną generację obowiązek zadbania o porównywalne warunki dostępu do niezbędnych zasobów naturalnych dla przyszłych pokoleń.

Mając na uwadze interdyscyplinarny charakter koncepcji zrównoważonego rozwoju, tj. łączący w sobie aspekty ekonomiczne, społeczne i środowiskowe, jej zastosowanie zostanie omówione na przykładzie branży spożywczej. Co istotne, rozwój tej branży jest determinowany m.in. właściwym funkcjonowaniem łańcuchów dostaw. Stąd celem publikacji jest przedstawienie idei zrównoważonego rozwoju oraz jej zastosowania w łańcuchach dostaw żywności - odgrywających ważną rolę w stosunkach międzynarodowych, w tym szczególnie będących przedmiotem zainteresowania polityki rolnej państw Unii Europejskiej na nowy okres programowy. W związku z tym w opracowaniu zostanie przedstawiona istota oraz ewolucja łańcuchów dostaw żywności, ze zwróceniem szczególnej uwagi na rosnącą potrzebę wdrażania $\mathrm{w}$ ich funkcjonowaniu elementów idei zrównoważonego rozwoju. Charakterystyka ostatniego zagadnienia będzie oparta na przedstawieniu celów zrównoważonych łańcuchów dostaw żywności oraz wybranych inicjatyw i działań wspomagających ich tworzenie i funkcjonowanie. Zostaną ponadto wskazane przykłady praktyk stosowanych przez przedsiębiorstwa na poszczególnych etapach łańcucha żywnościowego w kierunku zapewnienia zrównoważonego rozwoju oraz korzyści z tym związane.

W opracowaniu posłużono się metodą opisową i analizą literatury.

\section{Koncepcja zrównoważonego rozwoju i jej znaczenie dla sektora żywnościowego}

W literaturze przedmiotu można spotkać wiele podejść do interpretacji pojęcia zrównoważonego rozwoju. Jest to spowodowane nie tylko toczącymi się wieloletni- 
mi debatami na scenie międzynarodowej nad jego zastosowaniem w codziennym życiu człowieka oraz złożonością tej problematyki, ale przede wszystkim jej aktualnością i coraz głębszą świadomością jej zasadności wśród społeczeństwa. Początki idei zrównoważonego rozwoju sięgają pierwszej połowy XVIII wieku, oficjalnie zaś została ona włączona do obrad państw ONZ od tzw. pierwszego Szczytu Ziemi, zorganizowanego w 1972 r. W 1987 r. w raporcie pt. „Nasza wspólna przyszłość” opublikowanym przez tzw. Komisję Brundtland, przedstawiono znaczenie zrównoważonego rozwoju - jako takiego, który opiera się na zaspokajaniu potrzeb dzisiejszej ludzkości bez zagrożenia utraty tej możliwości przez kolejne pokolenia [Michalczyk 2017, s. 6-7]. W czasie kolejnych spotkań państw ONZ, zorganizowanych w ramach tzw. drugiego Szczytu Ziemi w 1992 r., Szczytu Milenijnego, Szczytu Ziemi 2002, Szczytu Rio +20 w 2012 r. oraz Szczytu w 2015 r. w Nowym Jorku, problematykę zrównoważonego rozwoju nie tylko bardziej umiędzynarodowiono poprzez rozszerzanie grupy wspólnie obradujących państw, ale również podkreślono jej wielowymiarowy charakter - przenosząc punkt jej ciężkości coraz bardziej poza pierwotny obszar, dotyczący środowiska naturalnego [Michalczyk 2017, s. 6-7; Sustainable... 2018]. Jednym z najważniejszych dokumentów wytyczających kierunki działań na rzecz zachowania zrównoważonego rozwoju była ustanowiona w ramach drugiego Szczytu Ziemi tzw. Agenda 21. Wyodrębniono w niej cztery główne obszary działań, poświęcone: sprawom społeczno-ekonomicznym, kwestiom dotyczącym gospodarowania zasobami naturalnymi, wzmacnianiu roli głównych grup społecznych i organizacji oraz możliwościom realizacyjnym [Agenda 21 2018]. Dokument ten stanowił punkt wyjścia do zwoływanych sukcesywnie spotkań państw, które doprowadziły m.in. do ustanowienia obecnie obowiązującej „Agendy na rzecz Zrównoważonego Rozwoju 2030” oraz do opracowywania strategii zrównoważonego rozwoju na poziomie krajowym z uwzględnieniem indywidualnych uwarunkowań wewnętrznych [Sustainable... 2018; Pichola i in. 2013].

Warto zaznaczyć, że koncepcja zrównoważonego rozwoju, mając charakter interdyscyplinarny ${ }^{1}$, jest traktowana również jako swoiste rozwiązanie systemowo-cywilizacyjne dla zachowania równowagi w biosferze przy utrzymaniu tempa rozwoju społeczno-gospodarczego i niepogorszeniu jakości życia człowieka. Ponadto wniosła wkład w rozwój nowej, również interdyscyplinarnej gałęzi - tzw. biogospodarki, opierającej się na wykorzystywaniu biotechnologii, bioprocesów i bioproduktów do zrównoważonego użytkowania zasobów odnawialnych w kontekście nieprzerwanie rosnącego na świecie zapotrzebowania na towary i usługi. Biogospodarka jest traktowana także jako inteligentna specjalizacja w sektorach powiązanych z rybactwem, rolnictwem, przetwórstwem spożywczym oraz przemysłem drzewnym, kosmetycznym, farmaceutycznym i energii odnawialnej, ukierunko-

1 Jest determinowana przez trzy wymiary, tj. ekologiczny - odnoszący się do wpływu działalności człowieka na środowisko naturalne, społeczny - dotyczący stosunków międzyludzkich, wartości i warunków egzystencjalnych oraz gospodarczy - skupiający się na dążeniu do dobrobytu, wzrostu gospodarczego i wdrażaniu efektywnych i innowacyjnych rozwiązań. 
wana dodatkowo na tworzenie zrównoważonych łańcuchów dostaw [Serafin 2014, s. 52]. Wśród państw w znacznym stopniu opierających przyszły rozwój gospodarczy na zrównoważonym podejściu do procesów gospodarowania można wskazać m.in. USA, Kanadę, RPA, Chiny, a szczególnie kraje UE [Bartoszczuk 2014, s. 361]. Te ostatnie starają się je realizować nie tylko na polu ogólnoświatowej współpracy, ale także wewnątrz ugrupowania. Przejawia się to we włączaniu idei zrównoważonego rozwoju do wszystkich możliwych obszarów działalności człowieka, w tym zwłaszcza do tych newralgicznych, narażonych na ryzyko wystąpienia daleko idących i nieodwracalnych skutków ewentualnego niekontrolowanego czy wręcz rabunkowego gospodarowania. Do takich obszarów należy sektor rolno-spożywczy. Ze względu na swoje strategiczne znaczenie, przejawiające się wielofunkcyjnym charakterem, leży on od wielu lat w centrum uwagi państw ugrupowania. Wielofunkcyjność ta obejmuje, obok dostaw żywności dla człowieka i zwierząt, coraz głębsze powiązanie go z innymi obszarami aktywności człowieka, w tym m.in. z sektorem energetycznym, z dbałością o zdrowie czy z promocją kraju na świecie. Ponadto wnosi ona wkład w realizację zadań z zakresu szeroko rozumianej ochrony środowiska, ze szczególnym uwzględnieniem zachowania jego czystości i bioróżnorodności. Jest to istotne wobec faktu, że wskazany sektor, obok motoryzacyjnego, wciąż należy do najważniejszych pod względem destruktywnego wpływu na stan środowiska naturalnego [Szymoniuk 2015, s. 360].

$\mathrm{W}$ minionych latach pojawiło się wiele inicjatyw unijnych ukierunkowanych na zrównoważony rozwój - począwszy od wytyczenia jego celów w traktacie amsterdamskim, poprzez strategię lizbońską, a skończywszy na szczycie w Goeteborgu w 2001 roku, kiedy to do debat włączono po raz pierwszy wymiar środowiskowy i opracowano kompleksową strategię zrównoważonego rozwoju Unii Europejskiej. Jej późniejsza rewizja w odpowiedzi m.in. na globalny kryzys oraz na potrzebę globalnej współpracy (zwłaszcza z państwami bardzo szybko się rozwijającymi) w zakresie dbania o zrównoważony rozwój doprowadziła do ustanowienia w 2010 r. strategii „Europa 2020” [Komunikat... 2005; Komunikat... 2010, s. 2-7]. Na marginesie warto dodać, że opracowany równolegle przez Unię program „Horyzont 2020" w dziedzinie badań i innowacji, który jest spójny z celami stawianymi we wspomnianej strategii, wnosi istotny wkład w rozwój m.in. sektora rolno-spożywczego przez upowszechnianie w nim procesów biotechnologicznych oraz wymusza na nim zmiany ukierunkowane na zrównoważony rozwój, m.in. przez promowanie niskoemisyjnych łańcuchów dostaw, sprzyjających zachowaniu różnorodności biologicznej i będących także konkurencyjnymi [Łybacka, Kocińska 2013, s. 14-17]. Bezpośrednie i szczegółowe rozwiązania dla implementacji koncepcji zrównoważonego rozwoju w sektorze rolno-spożywczym znalazły się z kolei we Wspólnej Polityce Rolnej (WPR). Prowadzone przez lata jej ciągłe modyfikacje doprowadziły w nowym okresie programowym na lata 2014-2020 do wyraźnego wyostrzenia celów, jakie stawiane są zrównoważonemu rozwojowi w trzech aspektach, tj. społecznym, ekonomicznym i ekologicznym, oraz do przełożenia ich na konkretne zadania, 
spójne z założeniami strategii „Europa 2020” [Rezolucja... 2011]. Wśród sześciu priorytetów określonych w WPR szczególne miejsce dla realizacji idei zrównoważonego rozwoju zajmuje ten dotyczący poprawy organizacji łańcuchów żywnościowych m.in. poprzez rozpowszechnianie systemów jakości, promocję lokalnych dostaw oraz wsparcie dla tworzenia zrzeszeń producentów. Zmiany w organizacji łańcucha związane są m.in. ze zbyt dużym rozdrobnieniem producentów rolnych w wielu krajach UE i przez to ich mała siłą przetargową, z wzajemną konkurencją o odbiorcę oraz ze słabym ich powiązaniem z rynkiem. Promowane skracanie powiązań łańcuchowych ma służyć głębszemu usamodzielnieniu się producentów rolnych, m.in. przez przejęcie przez nich dodatkowych funkcji, np. w zakresie przetwórstwa czy dystrybucji [MRiRW 2013, s. 15-17]. Można sądzić, że działania ukierunkowane na poprawę powiązań w łańcuchu żywnościowym nie tylko pozwalają poprawić pozycję konkurencyjną producentów rolnych, ale również rozwiązują wiele problemów i wyzwań związanych ze zrównoważonym rozwojem.

\section{Istota i ewolucja łańcucha dostaw żywności}

Istnieje wiele podejść do interpretacji łańcucha dostaw. W szerokim ujęciu jest on tworzony przez grupę podmiotów, których wspólne działania mają na celu zaspokojenie potrzeb określonych nabywców. Najogólniej obejmuje przepływy fizyczne (surowców, materiałów, półproduktów, gotowych produktów itp.) oraz informacji między uczestnikami, których łączą relacje dostawczo-odbiorcze. Wśród działań realizowanych przez poszczególne ogniwa łańcucha wytwórczości wyróżnia się przede wszystkim: rozwój, produkcję, sprzedaż, serwis, zaopatrzenie, dystrybucję, zarządzanie zasobami oraz funkcje wspomagające [Szymanowski 2008, s. 27-28]. Z kolei J. Witkowski określa je jako współdziałające w różnych obszarach przedsiębiorstwa wydobywcze, produkcyjne, handlowe, usługowe oraz ich klientów, pomiędzy którymi przepływają strumienie produktów, informacji oraz środków finansowych [Witkowski 2003, s. 17].

W literaturze przedmiotu oraz w rzeczywistości gospodarczej można wskazać wiele typów łańcuchów dostaw. Opierając się na specyfice produktu bądź branży, można wskazać następujące ich rodzaje [Anholcer, Kawa 2017, s. 16-17]: łańcuch dostaw elastyczny, szczupły, zwrotny, zielony, zimny, e-łańcuch dostaw, łańcuch dostaw FMCG (Fast Moving Consumer Goods), wysokich technologii, odzieży. Na tle przytoczonej kategoryzacji łańcuchów dostaw szczególnie ważny dla zobrazowania powiązań w sektorze żywnościowym jest łańcuch FMCG. Skupia on produkty codziennego użytku z różnych branż, w tym przede wszystkim żywność dla ludzi i zwierząt oraz używki, środki farmaceutyczne, kosmetyki, produkty z zakresu chemii gospodarczej i tzw. drobne artykuły AGD.

Żywność należy do szczególnej grupy produktów. Wynika to nie tylko z jej strategicznego znaczenia $\mathrm{w}$ postaci warunkowania przez nią funkcji życiowych i, co ważne, zdrowotnych człowieka, ale również z jej specyficznych walorów fizy- 
ko-chemicznych, determinujących sposób jej traktowania w całym procesie wytwarzania kończącym się dostawą do finalnego odbiorcy, który można obrazowo określić „od pola do stołu”. Ponadto dla wielu państw, w tym zwłaszcza UE, produkcja żywności jest jednym z priorytetowych sektorów, generujących korzyści natury nie tylko ekonomicznej, ale i pozaekonomicznej, co znalazło swoje odzwierciedlenie $\mathrm{w}$ polityce rolnej ugrupowania. W związku z tym niezmiernie ważne są powiązania budowane między podmiotami zaangażowanymi w wytwarzanie i dostawy żywności - tym bardziej, że są one rozciągnięte między trzy podstawowe sektory, tj. rolnictwo, przemysł spożywczy i handel oraz, co także z tego wynika, mogą skupiać dużą liczbę podmiotów. Dokonując spotykanego w literaturze przedmiotu uproszczenia w zakresie percepcji łańcucha dostaw żywności, utożsamiając go z łańcuchem żywnościowym [Motowidlak, Fajczak-Kowalska 2010; Kozera 2007; Jarzębowski, Klepacki 2013; Chechelski 2015], należy stwierdzić, że według normy ISO 22000 (będącej podstawą uzyskania certyfikatu systemu zarządzania bezpieczeństwem żywności) jest on sekwencją następujących po sobie zdarzeń zachodzących w produkcji, przetwórstwie, dystrybucji, magazynowaniu i postępowaniu z żywnością oraz jej składnikami, począwszy od produkcji pierwotnej (dotyczącej wytwarzania płodów rolnych i pasz) poprzez fazy przetwórstwa i dystrybucji, a skończywszy na finalnym odbiorcy (jednostkowym bądź zbiorowym). Należy tu uwzględnić też podmioty otoczenia dalszego, którymi są szczególnie: wytwórcy pestycydów i nawozów, producenci składników i substancji dodatkowych, dostawcy leków weterynaryjnych, operatorzy transportu i magazynowania, producenci maszyn i urządzeń, środków czyszczących i dezynfekujących, opakowań oraz dostawcy usług [Elementy... 2018].

Można wskazać wiele czynników oddziałujących na strukturę współczesnych łańcuchów dostaw żywności. Wynikają one w dużej mierze z szeroko rozumianej globalizacji i integracji regionalnej. Generalnie stały się one bardziej złożone za sprawą rozwoju sektorów współtworzących łańcuch dostaw żywności. Zmieniła się liczba podmiotów włączanych w dostawy, ich funkcje oraz charakter powiązań między nimi. Ponadto wzrosło znaczenie przedsiębiorstw działających w obszarze przemysłu środków produkcji i usług, realizujących wielorakie funkcje na rzecz innych podmiotów łańcucha dostaw, w tym przede wszystkim z zakresu transportu, magazynowania, marketingu, składowania i utylizacji odpadów czy pośrednictwa informacyjnego [Witkowski 2003, s. 17; Chechelski 2015, s. 48]. Dodatkowo pogorszeniu uległa pozycja przetargowa producentów rolnych, nie tylko z powodu plasowania się ich na początku coraz bardziej wydłużanych łańcuchów dostaw i - co $\mathrm{z}$ tego wynika - niewielkiego ich wpływu na cenę końcową produktu, ale również za sprawą wysokiego stopnia koncentracji i zorganizowania sektora handlowego w porównaniu z innymi ogniwami łańcucha [Chechelski 2015, s. 57-58; Rezolucja... 2011].

Biorąc pod uwagę mnogość i złożoność powiązań w łańcuchach żywnościowych, należy stwierdzić, że cykle dostaw uległy wydłużeniu. Jest to spowodowa- 
ne, jak już wspomniano, szeroko rozumianą globalizacją, która przynosząc postęp techniczny, dała możliwość realizacji transportu na duże odległości nie tylko dzięki nowoczesnym środkom łączności i komunikacji, ale także dzięki rozwojowi przetwórstwa, oferującego m.in. produkty o wydłużonym terminie przydatności i bardzo często o nadmiernie wzbogaconym i nieodżywczym składzie. W odpowiedzi na masową produkcję żywności wątpliwej jakości, i niekiedy niewiadomego pochodzenia z powodu zbyt rozbudowanych łańcuchów, a także na skutek pojawiających się na szeroką skalę przypadków wprowadzania do obrotu żywności niebezpiecznej dla zdrowia i życia człowieka podjęto działania na rzecz skracania łańcuchów dostaw, tak aby stawały się one bardziej przejrzyste. Ponadto dla wzmocnienia bezpieczeństwa żywości kraje Unii Europejskiej opracowały koncepcję nadzoru i monitorowania traceability ${ }^{2}$. Pozwala ona, poprzez oznaczenie partii produkcyjnych oraz wdrożenie systemu lokalizowania i śledzenia ich w całym łańcuchu dostaw, na szybkie odnalezienie ogniwa odpowiedzialnego za „wadliwy” produkt i na ewentualne wycofanie go z rynku. Obowiązkowe wdrażanie tego systemu wprawdzie wiąże się z nakładami finansowymi, ale w warunkach rosnącej konkurencji staje się strategicznym narzędziem w uzyskiwaniu przewagi konkurencyjnej poprzez budowanie marki bezpiecznego produktu oraz zaufania wszystkich podmiotów łańcucha dostaw ze szczególnym uwzględnieniem ostatniego, tj. konsumenta [Śliwczyński 2009]. Konsument w warunkach nieograniczonego dostępu do wiedzy i rosnącej świadomości otoczenia, zjawisk i procesów, których doświadcza i które współtworzy, w coraz większym stopniu brany jest pod uwagę przez przedsiębiorstwa w kreowaniu i zaspokajaniu potrzeb. Efektem tego jest ustawiczne modyfikowanie i rozszerzanie gamy produktów, nie tylko aby sprostać wysublimowanym potrzebom kupujących, ale również by wyprzedzić konkurencję.

Zwracając uwagę na zmieniające się upodobania konsumentów, warto odnotować główne trendy w konsumpcji w dzisiejszej gospodarce światowej, które oddziałują na charakter współczesnych łańcuchów dostaw żywności. Wśród trendów o charakterze długoterminowym wskazuje się na te powiązane ze zdrowiem, wygodą, zmysłowością, indywidualizmem, komfortem, potrzebą nawiązywania kontaktów i tzw. juwenalizacją. Dodatkowo można wskazać także tzw. regenerację wielopłaszczyznowy trend, który obejmuje nie tylko wiele obszarów konsumpcji, ale także wiele pokoleń, a w swej istocie sprowadza się do odwrotu od dominującej przez lata masowej hiperkonsumpcji w kierunku ograniczonej i dokonywanej z namysłem [Szepieniec-Puchalska 2012; Burgiel 2013, Kucharska 2014]. Przytoczone megatrendy przyczyniły się do różnicowania asortymentu żywności - nie tylko w zakresie jego rozszerzania, ale również pełnienia przez żywność dodatkowych funkcji, uwzględniwszy aspekt zdrowotności, atrakcyjność sensoryczną i dyspozycyjność w rozumieniu jej trwałości i łatwości przygotowania - i przez to

2 Artykuł 18 Rozporządzenia Parlamentu Europejskiego i Rady z 2002 r. [Rozporządzenie 2002] nakłada na podmioty obowiązek nadzorowania przepływu produktów oraz śledzenia ich w całym łańcuchu dostaw żywności. 
do dywersyfikacji łańcuchów dostaw w kierunku tworzenia się obok dotychczasowych, rozbudowanych powiązań również krótkich, dostarczających unikatową, regionalną i tradycyjną żywność. Warto dodać, że skracanie łańcuchów, ich większa przejrzystość oraz wzmocnienie w nich pozycji rolnika, który poprzez bezpośredni kontakt z finalnym odbiorcą żywności może szybciej i lepiej dopasowywać swoją ofertę do zmieniających się preferencji konsumentów, są jednymi z najważniejszych priorytetów zreformowanej polityki rolnej państw Unii na 2014-2020. Pozwalają one nie tylko poprawić konkurencyjność rolnictwa, ale także zachować dziedzictwo przyrodnicze, kulturowe, regionalne, produkcji oraz włączyć omawiany sektor w realizację celów zrównoważonego rozwoju.

\section{Cele zrównoważonego lańcucha żywnościowego}

Biorąc pod uwagę postępujący wpływ koncepcji zrównoważonego rozwoju na działalność gospodarczą, należy stwierdzić, że jej implementacja znajduje coraz większe uzasadnienie w kształtowaniu łańcuchów dostaw żywności. W efekcie powstające zrównoważone łańcuchy dostaw można określić za organizacją BSR (Business for Social Responsibility) jako system powiązań między podmiotami, zaangażowanych w cały cykl życia produktu przy uwzględnieniu osiągania nie tylko sukcesów komercyjnych, ale również poprawy dobrobytu społecznego oraz stanu środowiska naturalnego [PAIH 2018]. Doprecyzowaniem pojęcia zrównoważonych łańcuchów dostaw jest zwrócenie uwagi na trzy kluczowe cechy, jakimi powinny się one charakteryzować, tj. zrównoważony charakter, trwałość i równowagę. Głównymi celami zrównoważonych łańcuchów dostaw żywności, rozpatrywanymi na płaszczyźnie środowiska naturalnego, są szczególnie: przeciwdziałanie zanieczyszczeniu powietrza, wody i gleby, obniżanie poziomu hałasu oraz ochrona przed promieniowaniem. Z kolei wśród celów natury ekonomicznej wskazuje się m.in. potrzebę zachowania umiarkowanych cen żywności, utrzymanie stanowisk pracy, długoterminowy stabilny wzrost, sprawiedliwy handel, maksymalizację wartości dodanej i zwrotu z inwestycji oraz efektywne wykorzystanie zasobów. Natomiast w grupie aspektów społecznych można wskazać potrzebę poprawy i zachowania dobrego standardu życia dla wszystkich członków zaangażowanych w proces dostawczy żywności, ze szczególnym uwzględnieniem sektora rolnego, oraz promocję pozytywnych stosunków międzyludzkich w analizowanym łańcuchu. Można również wskazać cele żywnościowe, wśród których wyróżnia się zapewnienie nie tylko wystarczającej ilości pożywienia dla ludzkości, ale również jego odżywczy i wolny od zanieczyszczeń i szkodliwych substancji charakter. Ponadto dostawy żywności powinny być regularne i możliwe do wykonania w każdym miejscu i czasie dogodnym dla człowieka [Sznajder 2008, s. 156-157]. Realizacją wskazanych celów zainteresowanych jest wiele państw i przedsiębiorstw. Ich zaangażowanie w tym zakresie jest jednak zróżnicowane i wynika z indywidualnych uwarunkowań i priorytetów, jakie stawiają sobie wskazane podmioty gospodarki światowej. Nie bez znaczenia jest 
również postępująca świadomość społeczeństwa, które przez deklaracje zakupu tylko wybranych produktów żywnościowych także w coraz większym stopniu włącza się $\mathrm{w}$ promowanie zasad zrównoważonego rozwoju w produkcji, przetwórstwie i dostawach żywności.

\section{Wybrane inicjatywy oddziałujące na zrównoważone lańcuchy dostaw żywności}

W ostatnich latach podejmowanych jest wiele inicjatyw o randze globalnej, regionalnej i multilateralnej pozwalających na realizację celów stawianych zrównoważonym łańcuchom dostaw żywności. Obok wspomnianej działalności państw w ramach ONZ, która stworzyła fundamenty dla rozpowszechniania idei zrównoważonego rozwoju, można wskazać wiele przykładów działań w tym zakresie, realizowanych przez kraje, przedsiębiorstwa oraz społeczności w mniej lub bardziej sformalizowany sposób. Wśród nich na szczególną uwagę zasługują przedsięwzięcia o randze globalnej: Fair Trade i Slow Food. Pierwsze z nich jest promowane przez cztery najważniejsze organizacje międzynarodowe: FLO (Fairtrade International), WFTO (World Fair Trade Organization), EFTA (European Fair Trade Association) i FTAO (Fair Trade Advocacy Office), z których największe znacznie dla producentów spożywczych ma FLO. Jej znakiem Fair Trade opatrywane są m.in. suszone owoce, orzechy, banany, winogrona, kakao i wyroby z niego, trzcina cukrowa, kawa itp. Organizacja ta nadaje specyficzne oznaczenia żywności, przy której produkcji i handlu przestrzegane są standardy określone w tzw. Karcie Zasad Sprawiedliwego Handlu (opracowanej przez FLO i WFTO) [Bińkowski 2018; Sklepy... 2018; Karta ... 2018]. Warto dodać, że pierwsza międzynarodowa definicja tzw. sprawiedliwego handlu została opracowana w 1999 roku przez FINE, nieformalną platformę współpracy czterech częściowo wspomnianych międzynarodowych organizacji, tj. FLO, WFTO Europe (dawne NEWS - The Network of European Worldshops), WFTO oraz EFTA [FINE 2018]. Jej zbyt ograniczony kontekst wymusił jednak dalsze modyfikacje pojęcia, które w ostatecznym kształcie przybrało wielowymiarowy charakter, w którym uwypuklono podmiotowość uczestników w transakcjach handlowych. W efekcie w 2001 r. sprawiedliwy handel określono jako partnerstwo oparte na przejrzystości i dialogu, które pozwala realizować cele zrównoważonego rozwoju, a więc angażuje podmioty w łańcuchu dostaw w realizację działań ukierunkowanych nie tylko na aspekty ekonomiczne, ale także społeczne i środowiskowe. Odbywa się to np. przez efektywne wykorzystanie surowców ze źródeł odnawialnych, poprawę gospodarki odpadami czy rozpowszechnianie ekologicznych metod produkcji w rolnictwie. Ten ostatni aspekt nie tylko wiąże się z ochroną środowiska, ale pozwala na rozwijanie i przetrwanie krótkim łańcuchom dostaw, w których producenci rolni mają szansę na przechwycenie większej marży niż w przypadku łańcuchów tradycyjnych. Ponadto promowanie krótkich łańcu- 
chów dostaw wraz z długoterminową kontraktacją, która jest jednym z kluczowych założeń współpracy na warunkach Fair Trade, sprzyja m.in. poprawie bezpieczeństwa żywnościowego poprzez możliwość oferowania konsumentom stałych dostaw produktów po przystępnych cenach [Karta 2018; Sprawiedliwy... 2018]. Ruch Fair Trade jest zatem czynnikiem zmian i pożądanego kierunku rozwoju w handlu, który powinien przynosić wielowymiarowe i wymierne korzyści wszystkim uczestnikom łańcucha dostaw.

Obok oznaczenia Fair Trade w systemie certyfikacji na zasadach sprawiedliwego handlu można wskazać inne, także istotne i szeroko rozpowszechnione typy oznakowania żywności, które mają swój wkład w tworzenie zrównoważonych łańcuchów dostaw. Są to: WFTO, Naturland Fair, Fair for Life, Bio Equitable, Ecocert, Fair Trade USA (wyodrębniony w 2011 r. z systemu Fair Trade) czy unijne rolnictwo ekologiczne. Poza nimi funkcjonują, i niekiedy mylone są z systemem Fair Trade, równie ważne dla idei sprawiedliwego handlu inicjatywy, takie jak: Rainforest Alliance czy UTZ [Bińkowski 2018].

Drugim istotnym dla wdrażania zasad zrównoważonego rozwoju w łańcuchach dostaw żywności jest wspominany ruch slow food. Jego idea zrodziła się we Włoszech w odpowiedzi na szerzącą się w niepohamowanym tempie szkodliwą (w długiej perspektywie) dla człowieka konsumpcję żywności typu fast food. Jest to wprawdzie zrzeszenie nieformalne, jednak skala, na jaką rozpowszechniona jest ta alternatywna idea konsumpcji, pozwala traktować ją jako zjawisko wspierające i ukierunkowujące powiązania w łańcuchach dostaw pod kątem ich zrównoważonego charakteru. Przejawia się to przede wszystkim w ochronie produktów i tradycyjnych potraw, pochodzących z lokalnych rynków, która nie tylko daje zatrudnienie w branży, ale pozwala zachować zagrożoną wyginięciem różnorodność biologiczną. Ten coraz bardziej promowany na świecie ruch konsumencki jest efektem oddziaływania wielu czynników, w tym m.in. rosnącej mobilności przede wszystkim młodych osób, które są najbardziej podatne na przyswajanie globalnych bodźców kulturowych. Ponadto zarówno wśród młodszej, jak i starszej społeczności na znaczeniu zyskuje celebrowanie konsumpcji żywności, która przestaje być traktowana jedynie jako czynność zaspokajająca podstawową potrzebę życiową, ale staje się wyznacznikiem statusu społecznego, wyrafinowanego gustu, poczucia estetyki i tożsamości [Sowa 2017, s. 39].

Kolejną ważną inicjatywą na rzecz promowania zrównoważonych łańcuchów dostaw stało się powołanie do życia pozarządowej organizacji Business for Social Responsibility, skupiającej 250 przedsiębiorstw międzynarodowych, a także inne podmioty. Jej głównym celem jest wdrażanie do biznesu praktyk sprzyjających tworzeniu „sprawiedliwego i zrównoważonego świata”. Organizacja ta ma bardzo szerokie spektrum oddziaływania przez kojarzenie wspomnianych przedsiębiorstw z agencjami rządowymi oraz globalnymi i lokalnymi organizacjami pozarządowymi w celu wdrażania rozwiązań przynoszących wartość zarówno przedsiębiorstwom, jak i społeczeństwu. Według danych za rok 2016 we współpracę omawianej 
organizacji zaangażowały się 33 przedsiębiorstwa pochodzące z sektora rolno-spożywczego [BSR 2016]. Wśród nich można wskazać takie koncerny, jak np. Mars, Coca Cola, Japan Tobacco czy US Foods. Podmioty te, a także wiele innych działających poza tą organizacją, zaangażowane są w realizację idei zrównoważonego rozwoju przez implementację powszechnie uznawanej koncepcji CSR (Corporate Social Responsibility) opartej na prowadzeniu społecznie odpowiedzialnego biznesu, najlepiej we wszystkich sferach działalności przedsiębiorstwa, począwszy od wizji i strategii, przez m.in. łańcuchy dostaw, relacje z otoczeniem, a skończywszy na raportowaniu [Greszta 2011, s. 5].

Warto zaznaczyć, że w rozpowszechnienie koncepcji CSR zaangażowała się też międzynarodowa, pozarządowa Organizacja Normalizacyjna ISO, która usystematyzowała wiedzę na wskazany temat. W tym celu wydała normę ISO 26000, w której zwraca uwagę na trójwymiarowy charakter koncepcji CSR oraz jej wkład w zrównoważony rozwój przez pryzmat aspektów ekonomicznych, społecznych i środowiskowych, które powinny być zbalansowane i brane pod uwagę na każdym etapie działalności przedsiębiorstwa. Co więcej, omawiana koncepcja z racji swojej istoty powinna być nieodzownym członem realizowanej strategii każdego przedsiębiorstwa i być traktowana nie jedynie jako element kosztotwórczy (choć niewątpliwie nim jest), ale przede wszystkim budujący przewagi konkurencyjne [ISO 26000 2018].

Obok działań o zasięgu światowym na rzecz promowania idei zrównoważonego rozwoju w łańcuchach dostaw można wskazać także inicjatywy realizowane przez zrzeszenia określonych grup państw. Na wskazanym polu szczególne zaangażowanie wykazują m.in. państwa OECD (Organisation for Economic Cooperation and Development) oraz Unia Europejska. Jeśli chodzi o działalność OECD, to warto zwrócić uwagę na opracowanie przez nią już kilka dekad temu wytycznych odpowiedzialnego prowadzenia działalności biznesowej, tzw. RBC (Responsible Business Conduct), które po modyfikacji w obecnej postaci mają przyczyniać się do postępu gospodarczego, środowiskowego i społecznego przy zachowaniu zrównoważonego rozwoju. Warto zaznaczyć, że ostatnia aktualizacja omawianych wytycznych, przeprowadzona w 2011 r., rozszerzyła je o aspekty odpowiedzialnego zarządzania łańcuchem dostaw ze szczególnym uwzględnieniem przestrzegania praw człowieka oraz standardów ochrony środowiska [OECD 2011]. Obok ukierunkowanych na zrównoważony rozwój regulacji o charakterze ogólnym, OECD opracowała również zasady celowane w określone sektory, w tym dla sektora rolno-spożywczego. Zostały one przedstawione w dokumencie opracowanym wspólnie z FAO (Food and Agriculture Organization of the United Nations) pt. Guidance for Responsible Agricultural Supply Chains. Poradnik ten ma na celu wsparcie wszystkich przedsiębiorstw, zwłaszcza międzynarodowych, włączonych w łańcuchy dostaw, uwzględniając ich wielobranżowy charakter, począwszy od dostaw środków dla produkcji rolnej, poprzez produkcję rolną i przetwórstwo, a skończywszy na marketingu, dystrybucji i sprzedaży detalicznej, obejmując także usługi wspiera- 
jące funkcjonowanie łańcuchów dostaw [OECD/FAO 2016, s. 3, 15-16]. Zwrócono w nim uwagę na najważniejsze dla zachowania zrównoważonego rozwoju obszary ryzyka występujące $\mathrm{w}$ łańcuchach dostaw, na których musi się skupić przedsiębiorstwo w swojej działalności. Są nimi przede wszystkim: prawa człowieka i pracownicze, zdrowie i bezpieczeństwo, bezpieczeństwo żywnościowe i żywienie, prawo do posiadania i dostępu do zasobów naturalnych, ochrona i zrównoważone wykorzystanie zasobów naturalnych, dobrostan zwierząt oraz środowiska naturalnego, governance oraz wdrażanie technologii i innowacji przyjaznych otoczeniu [OECD/ FAO 2016, s. 25-29]. Ponadto opracowano dla przedsiębiorstw procedurę identyfikacji i radzenia sobie z możliwym do wystąpienia ryzykiem w łańcuchu dostaw, obejmującą m.in. środki zapobiegania i ograniczania jego istnienia we wskazanych obszarach [OECD/FAO 2016, s. 31-59]. Na przykład w celu minimalizacji ryzyka w obszarze zdrowie i bezpieczeństwo zaleca się m.in. śledzenie globalnych standardów bezpieczeństwa żywności na podstawie Codex Alimentarius, opracowanego w ramach współpracy FAO i WHO (World Health Organization) oraz dotyczących zdrowia zwierząt na podstawie wytycznych OIE (World Organisation for Animal Heath). Ponadto sugerowane jest wdrożenie koncepcji tzw. traceability dla poprawy bezpieczeństwa żywności oraz zarządzania w obszarze społecznym i środowiskowym, podnoszącym zaufanie publiczne [OECD/FAO 2016, s. 25-69]. Warto również zwrócić uwagę na sformułowane w omawianym poradniku OECD zalecenia dotyczące szczególnego traktowania tzw. ludności rdzennej ze względu na jej unikatowy charakter, często dyskryminowanej i ograniczanej w swoich prawach, a będącej nieodłącznym elementem żywotności tradycji i zwyczajów danego regionu [OECD/ FAO 2016, s. 78-80].

Jeśli chodzi o zaangażowanie państw UE we wdrażanie idei zrównoważonego rozwoju w łańcuchach dostaw żywności, to można wskazać wiele inicjatyw i działań bezpośrednio lub pośrednio z tym powiązanych. Obok potrzeby poprawy organizacji łańcucha żywnościowego przez jego konsolidację i skracanie na korzyść producentów rolnych, można znaleźć rozwiązania znajdujące się w innych priorytetach polityki rolnej Unii na lata 2014-2020, również ukierunkowane na wdrażanie idei zrównoważonego rozwoju do łańcuchów dostaw żywności. Są to np.: certyfikacja żywności regionalnej i tradycyjnej oraz produkowanej metodami ekologicznymi, wspieranie tworzenia grup producentów, budowa i modernizacja targowisk, zachowanie bioróżnorodności, promocja produkcji i hodowli rolnej prowadzonej metodami ekologicznymi, wspieranie gospodarki żywnościowej ukierunkowanej na zmniejszanie emisji gazów cieplarnianych, w tym zwłaszcza metanu, promowanie działalności gospodarczej na obszarach wiejskich poprzez wykorzystanie lokalnych zasobów czy wzmocnienie współpracy pomiędzy podmiotami naukowo-badawczymi i doradczymi a przedsiębiorstwami rolnymi, będącej podstawą długoterminowej konkurencyjności i zapewnienia zrównoważonego rozwoju sektora rolno-spożywczego [MRiRW 2013]. Mając na uwadze poprawę organizacji łańcucha żywnościowego, władze Unii poświęciły dużo uwagi w nowej polityce rolnej 
na upowszechnianie krótkich łańcuchów dostaw żywności oraz powiązanych z nimi lokalnych systemów żywności, oczekując, że przestaną być one jak dotychczas marginalną sferą funkcjonowania unijnego rolnictwa. W tym celu podjęły się realizacji projektu FAAN (Facilitating Alternative Agro-Food Networks), który został sfinansowany ze środków 7 Programu Ramowego. Stał się on bardzo ważny z punktu widzenia nie tylko upowszechniania alternatywnych kanałów dystrybucji żywności, ale również różnych jej kategorii, w tym np. pochodzącej z rolnictwa ekologicznego, biodynamicznego czy zintegrowanego. Przyjęte w projekcie postulaty są spójne z ideą zrównoważonego rozwoju oraz z zasadami sprawiedliwego handlu. Przejawia się to w osiąganiu różnej natury korzyści, począwszy od wymiernych i stabilnych wpływów finansowych niewielkich producentów rolnych, poprzez poprawę ich wizerunku jako mających wkład w utrzymanie kultury i tradycji narodowej, a skończywszy na polepszeniu warunków bytowych (poprzez konserwację krajobrazu) i zdrowotnych człowieka (wdrażanie technik produkcji przyjaznych środowisku oraz gwarantujących wysoką jakość odżywczą produktów). Wśród najbardziej pożądanych z punktu widzenia upowszechniania krótkich łańcuchów dostaw form sieci produkcji i dystrybucji żywności znalazły się m.in. tzw. zielone rynki, sprzedaż bezpośrednia z gospodarstwa, kosze regionalne, zamówienia publiczne u lokalnych producentów, miejskie ogrody, sieci specjalistycznych sklepów, a także tzw. rolnictwo wspierane. Ten ostatni aspekt wydaje się szczególnie ważny z punktu widzenia rozwijania zrównoważonych łańcuchów dostaw żywności, ponieważ podkreślone tu jest znaczenie budowania bezpośrednich relacji z konsumentami przez aktywne włączanie ich w warunki dostaw, dotyczące wyboru rodzajów wytwarzanych produktów oraz sposobu, miejsca i czasu ich realizacji. Niekiedy są oni nawet zaangażowani w ponoszenie kosztów produkcji w zamian za regularne dostawy [Grudziecka, Goszczyński 2010, s. 8-10].

Szczególnie ważną dla wytwórców żywności i, jak się wydaje, stabilną formą jej dystrybucji są zamówienia publiczne. W prawodawstwie europejskim dotyczącym tej kwestii coraz częściej można znaleźć odniesienia do upowszechniania krótkich łańcuchów dostaw żywności - np. poprzez określanie w zamówieniach minimalnego udziału produktów lokalnych. Dla przykładu w niektórych regionach Austrii w zamówieniach do publicznych ośrodków żywieniowych stosowane są kryteria dotyczące sezonowości, odległości dostaw oraz praktyk produkcyjnych przyjaznych środowisku naturalnemu. Z kolei we Włoszech władze regionalne starają się, aby do publicznych placówek trafiały produkty w przeważającej części lokalne, a niekiedy w całości ekologiczne [Local... 2012, s. 27; Grudziecka, Goszczyński 2010, s. 19]. Na marginesie warto dodać, że z zagadnieniem konsumpcji lokalnej żywności wiąże się rozwijający się na świecie ruch tzw. local eaters, mający swoje początki w USA i funkcjonujący już w wielu krajach UE (szczególnie jest zaawansowany we Francji, w regionie Île-de-France). Jego ideą jest spożywanie żywności wytworzonej w ograniczonej odległości od miejsca zamieszkania. W ten sposób wspierana jest produkcja nie tylko lokalnej, ale także sezonowej żywności [Local... 2012, s. 57]. 
Wśród wielu inicjatyw mających odniesienie do projektu FAAN za przykład można wskazać powstałe w Wielkiej Brytanii, w Manchesterze, przy wsparciu władz miasta, stowarzyszenie Food for Future, którego celem jest wdrażanie zasad etycznego handlu, odnowienie lokalnych tradycji, zapobieganie nierównościom oraz promocję zdrowej żywności. Z kolei we Francji funkcjonuje na znaczną skalę ruch La Via Campesina, dbający o lokalną wytwórczość, angażujący w nią także miejscową społeczność. Na Węgrzech, w Budapeszcie działa stowarzyszenie Kincsünk a Piac (,Rynek - nasz skarb”), które jest przykładem oddolnej inicjatywy w rozwijaniu krótkich łańcuchów dostaw żywności skupiających konsumentów, producentów i jej sprzedawców. Zrzeszenie o charakterze podobnym do ruchu węgierskiego działa także w dolnej Austrii - wspiera niewielkie gospodarstwa i dba o dostawy dla konsumentów zdrowej i smacznej żywności ze sprawdzonych źródeł, a ponadto zajmuje się organizacją profesjonalnej sieci sprzedaży [Grudziecka, Goszczyński 2010, s. 22-27].

Warto dodać, że promocja krótkich łańcuchów dostaw żywności - o większej przejrzystości i sprawniejszej kontroli przepływu zasobów względem tradycyjnych, często wydłużonych łańcuchów żywnościowych - ma istotne znaczenie dla zapewnienia bezpieczeństwa żywności, wyzwania, z którym mierzy się społeczność całego globu. Pożywienie dostarczane w krótkich cyklach dostaw, jak również niskiego przetwórstwa oraz spełniające standardy rolnictwa ekologicznego sprzyja ochronie środowiska naturalnego, a zatem pozytywnie wpływa na zachowanie zrównoważonego rozwoju.

Kolejnym przejawem zaangażowania się krajów Unii w rozwój zrównoważonych łańcuchów dostaw żywności jest utworzenie Europejskiej Sieci Dziedzictwa Kulinarnego. Funkcjonuje ona od 1995 roku i skupia Regionalne Sieci Dziedzictwa Kulinarnego z różnych części Europy. Należą do nich przede wszystkim restauracje, gospodarstwa rolne i agroturystyczne prowadzące sprzedaż, przetwórnie, hurtownicy i detaliści oraz inne podmioty sprzedające żywność. Głównym celem tej organizacji jest promowanie żywności pochodzącej z danego regionu oraz kojarzenie konsumentów z jej dostawcami. Obecnie do organizacji należy 28 regionów, w tym 9 z Polski [Europejska... 2018]. Warto również dodać, że na dystrybucji żywności lokalnej zależy nie tylko podmiotom działającym w ramach omawianej sieci, ale również innym, w tym supermarketom i restauracjom podążającym za wysublimowanymi oczekiwaniami konsumentów - ostatniego, rosnącego w siłę ogniwa łańcucha. Jak już wspomniano, ostateczni nabywcy wykazują coraz większe zainteresowanie pochodzeniem i jakością żywności, warunkami jej produkcji oraz wpływem jej wytwarzania na środowisko naturalne.

Przytoczone rozwiązania, a także inne, dotyczące unijnej polityki rolnej, są spójne z celami, jakie stawiane są przyszłemu rolnictwu unijnemu w zakresie wdrażania idei zrównoważonego rozwoju w łańcuchach dostaw żywności. Wśród głównych korzyści wynikających z jej zastosowania można wskazać te o charakterze ekonomicznym, jak np. podtrzymanie i dywersyfikację działalności rolniczej, 
wyrównanie szans podmiotów zaangażowanych w dostawy żywności, szerzenie bardziej sprawiedliwego handlu i zwalczanie nieuczciwych praktyk handlowych czy efektywniejsze wykorzystanie zasobów. Wśród społecznych aspektów należy wyróżnić m.in. przeciwdziałanie wykluczeniu społecznemu, podtrzymanie żywotności obszarów, zwłaszcza w miejscach o trudnych warunkach gospodarowania, zapewnienie miejsc pracy i przestrzeganie jej standardów, poprawę jakości życia, zachowanie dziedzictwa kulturowego czy np. zacieśnienie kontaktów na linii producent - konsument. Natomiast aspekty środowiskowe obejmują przede wszystkim zmniejszoną emisję gazów cieplarnianych - nie tylko poprzez odpowiednie praktyki rolne, ale także w wyniku transportu żywności na krótkie odległości. Ograniczenie strat żywności dzięki rozwojowi dostaw na lokalne rynki również niesie pozytywny skutek dla środowiska, jej produkcja bowiem pochłania niekiedy ogromne ilości zasobów naturalnych i zaburza równowagę ekologiczną, np. wskutek stosowania agresywnych metod hodowlano-uprawnych.

\section{Przykłady praktyk przedsiębiorstw na rzecz upowszechniania zrównoważonych lańcuchów dostaw żywności}

Uwzględniając trendy i innowacyjne rozwiązania zachodzące we współczesnej branży spożywczej, zdominowanej przez wiele globalnych koncernów, można wskazać wiele działań i inicjatyw realizowanych przez przedsiębiorstwa, w tym także przez mniejsze, ukierunkowanych na odpowiedzialne zarządzanie procesami w całym cyklu życia produktu oraz zgodnych z zasadami zrównoważonego rozwoju. Ich zastosowanie można prześledzić przez pryzmat kolejnych etapów realizacji czynności składających się na łańcuch dostaw. W obszarze zaopatrywania się w surowce są nimi m.in. minimalne ich wykorzystanie, uwzględniające także ich pochodzenie z recyklingu, szkodliwość dla środowiska naturalnego czy właściwą lokalizację. Z punktu widzenia przetwórstwa i produkcji - kolejnego etapu łańcucha dostaw - duże znaczenie ma dbałość o zamykanie obiegu wodnego i energetycznego, racjonalne zastosowanie masy opakowaniowej, wnikliwa ocena wyboru lokalizacji działalności oraz wytwarzanie produktów energooszczędnych, wodooszczędnych oraz niskokosztowych. Z kolei wobszarze transportu i dystrybucji dla wdrażania zasad zrównoważonego rozwoju szczególnie cenna jest optymalizacja tras i kursów, służąca minimalizacji emisji spalin, wykorzystanie transportu kombinowanego, eliminacja tzw. pustych przejazdów oraz dbanie o pełne załadowanie podczas przewozu, wykorzystanie innowacyjnych rozwiązań, np. poprzez zastosowanie kartonowych palet. W obszarze konsumpcji natomiast ważna jest m.in. optymalizacja zakupów, wybór produktów ekologicznych czy w opakowaniach nadających się do recyklingu oraz segregacja odpadów. Warto zaznaczyć, że na każdym etapie łańcucha dostaw powstają odpady, których zagospodarowanie staje się coraz bardziej ważną kwestią funkcjonowania przedsiębiorstw, zwłaszcza w branży spożywczej, w wymiarze nie tylko ekonomicznym, ale także środowiskowym i zdro- 
wotno-sanitarnym. Przydatnym rozwiązaniem jest tutaj wdrożenie systemu odbioru zużytych produktów czy opakowań oraz zamieszczanie na tych ostatnich informacji o wpływie na środowisko naturalne [Świetlińska 2014, s. 376].

Przytoczone działania pozwalają na osiąganie różnorakich korzyści w trzech wymiarach zrównoważonego rozwoju. Na etapie zaopatrzenia optymalne wykorzystanie surowców przynosi korzyści środowiskowe, społeczne oraz oszczędności wydatków. Z kolei w fazie przetwórstwa i produkcji do społecznych i środowiskowych korzyści należy m.in. zmniejszona ilość odpadów, kontrolowane zużycie zasobów naturalnych i energii oraz nowe miejsca pracy, a do ekonomicznych - niższe koszty dystrybucji i zużycia wody i energii. Na etapie dystrybucji i transportu można wskazać na większą dbałość o czystość powietrza oraz optymalizację procesów logistycznych, przynoszącą korzyści finansowe. W ostatnim członie łańcucha dostaw zrównoważone i świadome zakupy ograniczają zjawisko marnotrawstwa i ilość powstających odpadów oraz dają korzyści zdrowotne i skutkują optymalizacją wydatków. Wreszcie proces utylizacji odpadów przyczynia się do redukcji kosztów ich wywozu, a ich składowanie - do zmniejszenia zanieczyszczenia środowiska [Świetlińska 2014, s. 376].

Jednym z kluczowych czynników wpływających na realizację wskazanych działań i osiąganie korzyści spójnych z koncepcją zrównoważonego rozwoju jest wdrażanie nowoczesnych systemów i strategii zarządzania, pozwalających na włączenie do grupy liderów na wysoce konkurencyjnym rynku. Uwzględniając specyfikę branży spożywczej, która jest tzw. szybkim rynkiem zbytu i, co się z tym łączy, wymaga ciągłych dostaw pod kątem dużego wolumenu produkcji, należy stwierdzić, że szczególnie pożądanymi i cennymi atrybutami wdrażanych rozwiązań dla przedsiębiorstw są terminowość, oszczędność i „zwinność”. Są one odpowiednio podstawą następujących podejść: Just-in-Time (JIT), Lean Management (LM) oraz Agile Management (AM). Pierwszy z wymienionych systemów zarządzania nastawiony jest na eliminację zapasów, małe i częste dostawy, krótkie cykle dostaw oraz na zapewnienie wysokiej jakości. Warto jednak zaznaczyć, że nie wszystkie przedsiębiorstwa mogą w pełni korzystać z tego systemu. Wynika to ze specyfiki produkcji czy dostępności surowców w rolnictwie. Dotyczy to np. mleczarni, które nie mogą w pełni swobodnie decydować o ilości kupowanego surowca, który jest produkowany na bieżąco i musi być zagwarantowany jego ciągły odbiór. Ponadto warto mieć na uwadze, że pozorne oszczędności z tytułu eliminacji zapasów mogą przerodzić się w kosztowne dostawy. Podobnie jest z przetwórcami zbóż, owoców i warzyw. Tam decyzje dotyczące kształtowania wielkości zapasów ograniczone są ich dostępnością tylko w pewnym okresie roku. Zdecydowanie większe możliwości i korzyści z zastosowania omawianej strategii mają podmioty wykorzystujące surowiec już częściowo przetworzony, a największe - te znajdujące się na końcu łańcucha dostaw, tj. przedsiębiorstwa handlu hurtowego i detalicznego. Kolejnym innowacyjnym rozwiązaniem jest system Lean Management, którego zastosowanie jest podyktowane chęcią eliminacji wszelkich działań związanych z niegospodar- 
nością, co niewątpliwie sprzyja racjonalnemu wykorzystaniu czynników produkcji. Podobna w swej istocie do LM jest koncepcja działalności Agile Management, opierająca się na tzw. zwinnym podejściu do istniejącego łańcucha dostaw. Ma ona zastosowanie głównie w warunkach szybko zmieniających się oczekiwań konsumentów. Ponadto, podobnie jak poprzednie systemy zarządzania, kładzie ona nacisk na wysoką jakość, krótkie cykle dostaw oraz zadowolenie klienta. LM i AM mogą być wdrażane jednocześnie w przedsiębiorstwie jako wzajemnie uzupełniające się bądź pozwalające na osiąganie efektu synergii [Juchniewicz 2015].

W kontekście coraz większej dbałości o stan środowiska naturalnego poprzez zagospodarowanie odpadów, w tym wykorzystanie ich na cele energetyczne, warto odnieść się do koncepcji zarządzania tzw. zamkniętą pętlą łańcucha dostaw CLSCM (Closed Loop Supply Chain Management). Jej zastosowanie w przemyśle spożywczym jest szczególnie istotne ze względu na ilości powstających odpadów i ich specyficzny charakter. Biorąc pod uwagę mnogość i złożoność funkcjonowania poszczególnych branż przemysłu spożywczego, można wskazać różne typy zamkniętych pętli łańcucha dostaw. Mogą to być najprostsze, obejmujące wyłącznie jednego producenta (tzw. recykling wewnętrzny), przez bardziej rozbudowane, powstające w drodze współpracy dwóch podmiotów z tej samej branży (np. mięsnej) lub różnych branż (np. mięsnej i paszowej), gdzie jeden przekazuje powstałe odpady drugiemu na cele produkcyjne, a skończywszy na tworzeniu zamkniętej pętli na całej długości łańcucha dostaw, włączywszy konsumenta. Ten ostatni model pętli jest najbardziej pożądany z punktu widzenia idei zagospodarowywania odpadów, która przez dążenie do całkowitego ich ponownego wykorzystania i traktowanie utylizacji jako ostateczności staje się coraz trudniejsza w realizacji [Szmelter 2016].

Innym wartym uwagi sposobem mierzenia się przedsiębiorstw łańcucha dostaw z wyzwaniami zrównoważonego rozwoju jest posługiwanie się koncepcjami 3R oraz LCA (Life Cycle Assessment). Ta pierwsza, oparta na trzech filarach, określanych słowami: reduce, reuse, recycle, jest ukierunkowana na minimalizację negatywnego wpływu na środowisko naturalne oraz na zrównoważone gospodarowanie odpadami. Przejawia się to ograniczaniem zużycia surowców i energii przez wielokrotne ich wykorzystanie i kontrolowaną ilość produkcji [Jastrzębska 2015]. Z kolei koncepcja LCA jest narzędziem wykorzystywanym przez przedsiębiorstwa do pomiaru wpływu danego produktu na środowisko przez ustalenie np. śladu węglowego, który wskazuje na wielkość emisji gazów cieplarnianych powstających w czasie produkcji. Takie pomiary są stosowane przez wiele przedsiębiorstw, w tym m.in. przez Danone czy Coca-Colę, które wymuszają także ich raportowanie na swoich kontrahentach [Wernicka 2014, s. 8-10; Dostatni, Kowalewska 2016].

Przytoczone rozwiązania, udoskonalające funkcjonowanie łańcuchów dostaw, pozwalają przedsiębiorstwom nie tylko być konkurencyjnymi, ale także spełniać coraz bardziej wysublimowane oczekiwania konsumentów. Oczekują oni bowiem, obok nieskrępowanego geograficznie dostępu do urozmaiconego asortymentu po przystępnych cenach, gwarancji spełnienia standardów żywności bezpiecznej 
i wolnej od zanieczyszczeń. Ponadto ich uwaga jest coraz częściej przekierowywana na inne niematerialne atrybuty nabywanych produktów, powiązane z wdrażaniem przez przedsiębiorstwa zasad zrównoważonego rozwoju, takie jak np. przyjazne środowisku warunki prowadzonych hodowli i upraw, współpraca z lokalnymi dostawcami czy wykorzystywanie recyklingu.

Zrównoważony rozwój staje się zatem jednym z najważniejszych obszarów funkcjonowania łańcuchów dostaw żywności, a przedsiębiorstwa podejmują wiele działań spójnych z omawianą koncepcją. Można stąd wskazać na upowszechnianie się pewnych trendów, ukierunkowanych m.in. na zarządzanie różnorodnością w łańcuchach, przy uwzględnieniu kwestii włączenia i wzmocnienia pozycji kobiet oraz osób niepełnosprawnych, oraz na inwestowanie w rynki lokalne w celu rozwoju społeczności lokalnej i np. redukcji kosztów transportu, a tym samym ograniczania ryzyka zarządzania w ramach krótkich łańcuchów dostaw. Innym ważnym trendem jest nacisk na edukację i współpracę z dostawcami w celu wypracowania wspólnych wartości oraz na angażowanie partnerów biznesowych w działania społeczne. Ponadto na znaczeniu zyskał trend tworzenia tzw. zielonych łańcuchów dostaw, które są niejako efektem konkretyzacji wytycznych zrównoważonego rozwoju ze szczególnym uwzględnieniem aspektów środowiskowych na każdym z ich etapów [Krzysztofek 2014, s. 1944; Witkowski, Pisarek 2017, s. 22-24].

\section{Podsumowanie}

We współczesnej gospodarce światowej wdrażanie idei zrównoważonego rozwoju wydaje się nieodzownym elementem współpracy międzynarodowej państw oraz przedsiębiorstw, zarówno krajowych, jak i ponadnarodowych. Szczególnie ważne jest wdrażanie jej w sektorze rolno-spożywczym, w którym codzienna produkcja i dostawy żywności istotnie obciążają środowisko naturalne. Ponadto zawiązywane w nim łańcuchy dostaw budzą wiele kontrowersji, zwłaszcza pod kątem osiągania nierównomiernych korzyści przez poszczególne ogniwa, szczególnie przez producentów rolnych - najważniejszy podmiot w łańcuchu, dostarczający surowiec na potrzeby kolejnych jego ogniw.

Inną ważną kwestią powiązaną z funkcjonowaniem łańcuchów dostaw jest zapewnienie bezpieczeństwa żywności. Dążenie do transparentnego charakteru łańcuchów i do zapewnienia standardów środowiskowych, jak również dbanie o aspekty natury społecznej, np. przez podtrzymanie rodzinnych gospodarstw, oferujących ekologiczną czy regionalną żywność i tym samym przeciwdziałających powszechnej homogenizacji bardzo często szkodliwych wzorców żywieniowych, jest bardzo istotne dla zachowania dobrego stanu zdrowia obecnego i przyszłych pokoleń. Na skuteczność wdrożenia koncepcji zrównoważonego rozwoju w łańcuchach dostaw żywności wpływa jej implementacja nie tylko w relacjach między podmiotami, ale również na każdym etapie działalności poszczególnych przedsiębiorstw, począwszy od tworzenia wizji i strategii przedsiębiorstwa, a skończywszy 
na raportowaniu. Warto w tym kontekście zwrócić uwagę na znamienne zaangażowanie państw UE we wdrażanie idei zrównoważonego rozwoju do polityk wspólnotowych, w tym do rolnej. Przejawia się to w licznych formach aktywizacji i wsparcia producentów rolnych, a szczególnie w zachęcaniu do zawiązywania krótkich łańcuchów dostaw. Te ostatnie, jak wykazano, obok wsparcia producentów rolnych wnoszą znaczny wkład w realizację celów przypisywanych zrównoważonemu rozwojowi.

\section{Literatura}

Agenda 21, 2018, https://pl.wikipedia.org/wiki/Agenda_21, 03.03.2018.

Anholcer M., Kawa A., 2017, Model tańcucha dostaw z ograniczeniami wykluczającymi, [w:] M. Cichosz, K. Nowicka, A. Pluta-Zaremba (red.), Zarzadzanie tańcuchem dostaw i logistyka w XXI wieku, Oficyna Wydawnicza SGH, Warszawa, s. 15-30.

Bartoszczuk P., 2014, Perspektywy rozwoju biogospodarki, ZS WSH Zarządzanie, nr 1, s. 357-364.

Bińkowski B., 2018, Systemy certyfikujace Fair Trade, http://sklepfairtrade.pl/Systemy-certyfikujace-Fair-Trade-clinks-pol-183.html, 03.03.2018.

BSR, 2016, BSR Report, https://www.bsr.org/reports/BSR_Report_2016.pdf, 03.03.2018.

Burgiel A., 2013, Re-generacja jako megatrend w zachowaniach konsumentów - czy Polacy sa na nia gotowi?, Zeszyty Naukowe Uniwersytetu Szczecińskiego, nr 777, s. 11-24.

Chechelski P., 2015, Ewolucja łańcucha żywnościowego, [w:] I. Szczepaniak, K. Firlej (red.), Przemyst spożywczy - makrootoczenie, inwestycje, ekspansja zagraniczna, Warszawa-Kraków, Fundacja UE w Krakowie, s. 45-63.

Dostatni E., Kowalewska A., 2016, Analiza prośrodowiskowa wyrobu i propozycja jego udoskonalenia $z$ wykorzystaniem narzędzia informatycznego, [w:] R. Knosala (red.), Innowacje w zarzadzaniu i inżynierii produkcji, t. 2, Oficyna Wydawnicza Polskiego Zarządzania Produkcją, Opole, s. 701712.

Elementy łańcucha żywnościowego, 2018, http://quality-management.pl/haccp/elementy-lancucha-zywnosciowego/, 03.03.2018.

Europejska Sieć Regionalnego Dziedzictwa Kulinarnego, 2018, https://pl.wikipedia.org/wiki/Europejska_Sie\%C4\%87_Regionalnego_Dziedzictwa_Kulinarnego, 03.03.2018.

FINE, 2018, https://en.wikipedia.org/wiki/FINE, 03.03.2018.

Greszta M., 2011, Co to znaczy być liderem SCR na rynku, „Kompendium SCR” - niezależny dodatek tematyczny dystrybuowany wraz z „Rzeczpospolitą”.

Grudziecka L., Goszczyński W., 2010, Alternatywne sieci produkcji i dystrybucji żywności - doświadczenia polskie i europejskie, Toruń-Warszawa, Forum Aktywizacji Obszarów Wiejskich, UMK.

ISO 26000, 2018, http://www.odpowiedzialnafirma.pl/o-csr/iso-26000, 03.03.2018.

Jarzębowski S., Klepacki B., 2013, Łańcuchy dostaw w gospodarce żywnościowej, Zeszyty Naukowe SGGW w Warszawie - Ekonomika i Organizacja Gospodarki Żywnościowej, nr 103, s. 107-117.

Jastrzębska E., 2015, Środowisko przyrodnicze jako niemy interesariusz społecznie odpowiedzialnego przedsiębiorstwa. Dobre praktyki biznesu w Polsce, Logistyka Odzysku, nr 2, s. 49-51.

Juchniewicz M., 2015, Innowacje w logistyce tańcucha dostaw żywności, Zeszyty Naukowe Uniwersytetu Szczecińskiego, nr 875, s. 473-482.

Karta Zasad Sprawiedliwego Handlu, 2018, http://www.sprawiedliwyhandel.pl/wp-content/ uploads/2017/01/Karta_Zasad_Sprawiedliwego-Handlu.pdf, 03.03.2018. 
Komunikat Komisji do Rady i Parlamentu Europejskiego - projekt deklaracji zasad przewodnich w zakresie zrównoważonego rozwoju, 2005, COM/2005/0218 z 25.05.2005.

Komunikat Komisji EUROPA 2020. Strategia na rzecz inteligentnego i zrównoważonego rozwoju sprzyjajacego właczeniu społecznemu, 2010, KOM (2010) z 03.03.2010.

Kozera M., 2007, Struktura łańcucha żywnościowego oraz zmiany relacji producent-konsument w Polsce $i$ krajach UE, Zeszyty Naukowe SGGW w Warszawie - Problemy Rolnictwa Światowego, t. 17 , z. 2, s. $240-246$.

Krzysztofek A., 2014, Zrównoważone zarządzanie łańcuchem dostaw jako element wdrażania społecznej odpowiedzialności, Logistyka, nr 5, s. 1939-1949.

Kucharska B., 2014, Trendy w zachowaniach konsumentów jako uwarunkowanie innowacji w handlu detalicznym, Studia Ekonomiczne, nr 187, s. 220-228.

Local Food and Short Supply Chains, 2012, EU Rural Review, nr 12.

Łybacka K., Kocińska E., 2013, Horyzont 2020. Program Ramowy UE w zakresie badań naukowych i innowacji, Zibi-Grafia.

Michalczyk J., 2017, Znaczenie lokalnej żywności oraz krótkich łańcuchów dostaw w kształtowaniu zrównoważonego rozwoju rolnictwa i obszarów wiejskich w Unii Europejskiej, Ekonomia Międzynarodowa, nr 17, s. 5-20.

Motowidlak U., Fajczak-Kowalska A., 2010, Wartość dodana w tańcuchu dostaw żywności, Zeszyty Naukowe SGGW w Warszawie - Problemy Rolnictwa Światowego, t. 10, z. 2, s. 91-99.

MRiRW, 2013, Wstępny zarys. Program Rozwoju Obszarów Wiejskich 2014-2020, Warszawa.

OECD, 2011, OECD Guidelines for Multinational Enterprises, OECD Publishing.

OECD/FAO, 2016, OECD-FAO Guidance for Responsible Agricultural Supply Chains, OECD Publishing, Paris.

PAIH, 2018, Wytyczne OECD w kontekście zarządzania tańcuchem dostaw, http://www.paih.gov. pl/20120628/wytyczne_oecd_w_kontekscie_zarzadzania_lancuchem_dostaw, 03.03.2018.

Pichola I., Dziamara-Rzucidło K., Zwyrtek M., 2013, Miasta na drodze do zrównoważonego rozwoju, PWC.

Rezolucja Parlamentu Europejskiego z dnia 23 czerwca 2011 r. w sprawie WPR do 2020 r.: sprostać wyzwaniom przyszłości związanym z żywnościa, zasobami naturalnymi oraz aspektami terytorialnymi, 2011, 2011/2051(INI).

Rozporządzenie (WE) nr 178/2002 Parlamentu Europejskiego i Rady z dnia 28 stycznia 2002 r. ustanawiające ogólne zasady i wymagania prawa żywnościowego, powołującego Europejski Urząd ds. Bezpieczeństwa Żywności oraz ustanawiającego procedury w zakresie bezpieczeństwa żywności, 2002, OJ L 31 z 1.2.2002.

Serafin M., 2014, Biogospodarka w inteligentnym i zrównoważonym rozwoju Unii Europejskiej, [w:] T. Jemczura, H.A. Kretek (red.), Zrównoważony rozwój. Debiut naukowy 2013, Racibórz, Wyd. PWSZ, s. 52-60.

Sklepy $i$ organizacje, 2018, http://www.fairtrade.org.pl/podmioty/organizacje-miedzynarodowe/, 03.03.2018.

Sowa A., 2017, Jutro kij, dziś marchewka, Polityka, nr 39.

Sprawiedliwy handel, 2018, https://pl.wikipedia.org/wiki/Sprawiedliwy_handel, 03.03.2018.

Sustainable Development Goals, 2018, http:/ungc.org.pl/sdg/sustainable-develompent-goals/, 03.03.2018.

Szepieniec-Puchalska D., 2012, Polscy konsumenci w obliczu megatrendów w konsumpcji, Konsumpcja i Rozwój, nr 1, s. 85-100.

Szmelter A., 2016, Specyfika zarządzania zamknięta pętla łańcucha dostaw w sektorze spożywczym, Logistyka Odzysku, nr 3, s. 20-26.

Sznajder M., 2008, The concept of sustainable food chain (case study - the dairy food chain), Journal of Agribusiness and Rural Development, z. 2 (8), s. 155-163. 
Szymanowski W., 2008, Zarządzanie tańcuchami dostaw żywności w Polsce. Kierunki zmian, Difin, Warszawa.

Szymoniuk B., 2015, Globalne marnotrawstwo zasobów - wyzwania dla zrównoważonego marketingu, Prace Naukowe Uniwersytetu Ekonomicznego we Wrocławiu, nr 406, s. 358-366.

Śliwczyński B., 2009, Bezpieczne tańcuchy dostaw, Logistyka, nr 1, s. 16-20.

Świetlińska M., 2014, Zrównoważony łańcuch dostaw żywności - studium przypadku, Prace Naukowe Akademii im. Jana Długosza w Częstochowie. Pragmata Tes Oikonomias, z. 8, s. 373-382.

Wernicka M., 2014, Doświadczenie w metodyce liczenia Carbon Footprint w przedsiębiorstwach $w$ Polsce, http://zielonewydarzenia.pl/files/pliki/Wernicka_Do\%C5\%9Bwiadczenie_w_metodyce_liczenia_CF.pdf, 03.03.2018.

Witkowski J., 2003, Zarządzanie łańcuchem dostaw, PWE, Warszawa.

Witkowski J., Pisarek A., 2017, Istota zielonych łańcuchów dostaw - propozycja systematyzacji pojęć, Studia Ekonomiczne, nr 315, s. 11-26. 